\section{Comparison of Paper Bags, Calcium Carbonate, and Shade Nets for Sunscald Protection in 'Murcott' Tangor Fruit}

\author{
Meng-Shiun Tsai, Tan-Cha Lee, and Pai-Tsang Chang ${ }^{1}$
}

ADDITIONAL INDEX WORDS. citrus, nylon net, whitener

Summary. 'Murcott' tangor (Citrus reticulata $\times$ Citrus sinensis) is susceptible to sunscald injury due to high temperatures during summer in Chiayi, Taiwan. The average rate of sunscald damage in 'Murcott' tangor fruit is $13.6 \%$ when no protective measures are used. The objective of this study was to compare the effects of covering developing fruit with white paper bags, calcium carbonate, or shade nets to reduce the effects of sunscald. A significant reduction in sunscald was realized when using white paper bags, calcium carbonate spray, or white, green, and black shading nets. Calcium carbonate spraying was the most rapid method, but was less effective in controlling sunscald, and resulted in the lowest photosynthetic rate. Compared with trees under shade nets, those under black netting had larger and heavier fruit. There were no significant differences in peel color, titratable acid (TA), total soluble solids/titratable acid (TSS/TA) ratio, or respiration rate for the evaluated treatments. Although all shading materials reduced sunscald, the use of shade net was the most effective in controlling damage related to this, and thus can have significant benefits for commercial citrus (Citrus sp.) orchard operations.

S unburn due to high temperatures or high intensities of light radiation can significantly diminish the quality of fruit. Sunburn has been reported in apple [Malus $\times$ domestica (Bergh et al., 1980; Parchomchuk and Meheriuk, 1996; Piskolczi et al., 2004; Schrader et al., 2001, 2003; Simpson et al., 1988; Warner, 1997)], tomato [Solanum lycopersicum (Rabinowitch et al., 1974)], grape [Vitis sp. (Greer and Borde, 2006; Tarara and Spayd, 2005)], avocado [Persea americana (Schroeder and Kay, 1961)], and citrus (Futch and Jackson, 1993; Jifon and Syvertsen, 2003a; Myhob et al., 1996). Schrader et al. (2001) described two types of sunburn that occurred in apple (e.g., sunburn necrosis and sunburn browning), and a third type (photooxidative stress) is mentioned in Felicetti (2003). Sunburn necrosis occurs when the surface temperatures of the fruit reached (mean $\pm \mathrm{sE}$ ) $52 \pm 1{ }^{\circ} \mathrm{C}$ for $10 \mathrm{~min}$, leading to the breakdown of cell membranes (Schrader et al., 2001). Sunburn browning occurs when the surface temperature of fruit reaches 46 to $49^{\circ} \mathrm{C}$ under sunlight (Schrader et al., 2001). The third type of sunburn, photooxidative sunburn, occurs

Department of Horticultural Science, National Chiayi University, 300 Xuefu Road, Chiayi City, 60004 Taiwan

${ }^{1}$ Corresponding author. E-mail: ptchang@mail.ncyu. edu.tw. when shaded apple is suddenly exposed to sunlight, causing photooxidative stress (Felicetti, 2003). The visible symptoms of sunscald in citrus fruit are irregular yellow or brown blotches on the peel (Myhob et al., 1996), although there is a report that granulation may also be caused by severe heat injury sunscald (Chikaizumi, 2000). Under high ambient temperatures, citrus fruit are particularly prone to heat stress, because the tree canopy temperature can easily exceed ambient temperatures by up to $9{ }^{\circ} \mathrm{C}$ (Syvertsen and Albrigo, 1980). In addition, when citrus are grown in warm subtropical regions, the average air temperatures during the summer are above $31^{\circ} \mathrm{C}$, and leaf temperatures can reach 39 to $41{ }^{\circ} \mathrm{C}\left[8\right.$ to $10{ }^{\circ} \mathrm{C}$ above air temperatures (Syvertsen and Lloyd, 1994)].
This range of temperatures is far above the optimum for the net carbon dioxide $\left(\mathrm{CO}_{2}\right)$ assimilation rate $[25$ to $30{ }^{\circ} \mathrm{C}$ (Spiegel-Roy and Goldschmidt, 1996)], and might be associated with stomatal closure and reductions in the net $\mathrm{CO}_{2}$ assimilation rate, growth, and yield (Goldschmidt, 1999).

Thin-skinned citrus fruit like 'Murcott' tangor are most prone to sunscald when facing the sun. There is evidence that the surface temperature of melon (Cucumis melo) and tomato can be 40 and $50{ }^{\circ} \mathrm{C}$, respectively, when they face the sun (Schroeder, 1965). Furthermore, the skin temperature of grape can exceed air temperatures by up to $12{ }^{\circ} \mathrm{C}$ under direct sunlight (Kliewer and Lider, 1968; Smart and Sinclair, 1976). In addition, it was found that sunburn occurs in apple only when the fruit surface temperature exceeds $45^{\circ} \mathrm{C}$ (Ritenour et al., 2001; Schrader et al., 2001). As a result, when air temperature reaches $30{ }^{\circ} \mathrm{C}$ in the field, the peel temperature of many fruit can rise to a level at which sunscald damage occurs. Moreover, when fruit and vegetables are cultivated in subtropical and tropical climates, the surface temperature can reach more than $40^{\circ} \mathrm{C}$ under direct sunlight (Syvertsen and Albrigo, 1980; Syvertsen and Lloyd, 1994; Woolf and Ferguson, 2000).

There are several techniques that can be used to reduce the occurrence of sunscald, such as bagging (Hofman et al., 1997), whiteners (Glenn et al., 2002; Melgarejo et al., 2004; Sibbett et al., 1991; Wand et al., 2006), ascorbic acid spraying (Andrews et al., 1999; Johnson et al., 1999), and the use of shade nets (Dussi et al., 2005; Gindaba and Wand, 2005; Raveh et al., 2003). Although shading of fruit from sunlight is the ideal way to reduce the likelihood of sunscald, it

\begin{tabular}{llll}
\hline $\begin{array}{l}\text { Units } \\
\begin{array}{l}\text { To convert U.S. to SI, } \\
\text { multiply by }\end{array}\end{array}$ & U.S. unit & SI unit & $\begin{array}{l}\text { To convert SI to U.S., } \\
\text { multiply by }\end{array}$ \\
\hline 29.5735 & $\mathrm{fl} \mathrm{oz}$ & $\mathrm{mL}$ & 0.0338 \\
7.8125 & $\mathrm{fl} \mathrm{oz} / \mathrm{gal}$ & $\mathrm{mL} \cdot \mathrm{L}^{-1}$ & 0.1280 \\
65.1985 & $\mathrm{fl} \mathrm{oz} / \mathrm{lb}$ & $\mathrm{mL} \cdot \mathrm{kg}^{-1}$ & 0.0153 \\
0.3048 & $\mathrm{ft}$ & $\mathrm{m}$ & 3.2808 \\
0.0929 & $\mathrm{ft}^{2}$ & $\mathrm{~m}^{2}$ & 10.7639 \\
3.7854 & gal & $\mathrm{L}$ & 0.2642 \\
2.54 & inch $(\mathrm{es})$ & $\mathrm{cm}$ & 0.3937 \\
25.4 & inch $(\mathrm{es})$ & $\mathrm{mm}$ & 0.0394 \\
16.3871 & inch & $\mathrm{cm}$ & 0.0610 \\
28.3495 & $\mathrm{Oz}$ & $\mathrm{g}$ & 0.0353 \\
28,350 & $\mathrm{oz}$ & $\mathrm{mg}$ & $3.5274 \times 10^{-5}$ \\
305.1517 & $\mathrm{Oz} / \mathrm{ft}^{2}$ & $\mathrm{~g} \cdot \mathrm{m}^{-2}$ & 0.0033 \\
$\left({ }^{\circ} \mathrm{F}-32\right) \div 1.8$ & ${ }^{\circ} \mathrm{F}$ & ${ }^{\circ} \mathrm{C}$ & $\left({ }^{\circ} \mathrm{C} \times 1.8\right)+32$ \\
& & & \\
\end{tabular}

Hortlechnology · October $201323(5)$ 
is still unclear which approach is most effective and economical with regard to commercial citrus orchards. The major aim of this study is to evaluate several possible sunscald control strategies or methods, and measure their effectiveness in reducing sunburn symptoms and also to describe their effects on fruit quality. The experiment was conducted with 'Murcott' tangor trees, where shading was applied during the hottest months (July to October) of the year in Taiwan.

\section{Materials and methods}

ORCHARD CHARACTERISTICS. The research orchard was located in Chiayi County, Taiwan (lat. $23.35^{\circ} \mathrm{N}$, long. $120.31^{\circ} \mathrm{E}$, elevation $\left.150 \mathrm{~m}\right)$.
Experimental trees were 15-year-old 'Murcott' tangor arranged in a typical open-center training system with similar canopy surface areas of $\approx 12.3 \mathrm{~m}^{2}$ as described in Morse and Robertson (1987) and planted with a northwest to southeast orientation at a spacing of $3.5 \times 1.5 \mathrm{~m}$. This area has a wholeyear freeze-free growing period, and an average annual precipitation of $\approx$ $2.76 \mathrm{~m}$. Trees were grown following standard horticultural practices, as well as disease and pest control measures.

Experimental DESign. A completely randomized design with three replications was used in this trial, with one 'Murcott' tree used in each treatment. Treatment 1 was a control, without any shading treatment (Fig. 1A).
Treatment 2 used a white paper bag $(27.8 \times 15.8 \mathrm{~cm})$ to cover each fruit (Fig. 1B). In Treatment 3, ground calcium carbonate $\left[\mathrm{CaCO}_{3}(99 \%\right.$; Fisher Scientific, Pittsburgh, PA)] solution was sprayed at a concentration of $3 \%$ and was first applied on 22 July 2008. A surfactant (20\% Tween 20 ; Sigma-Aldrich, St. Louis, MO) was used at a rate of $0.2 \mathrm{~mL} \cdot \mathrm{L}^{-1}$ water. The whole tree canopy was sprayed with (mean \pm SE) $8 \pm 0.5 \mathrm{~L} \mathrm{CaCO}_{3}$ solution uniformly using a backpack spray apparatus (Fig. 1C). The $\mathrm{CaCO}_{3}$ solution was resprayed if needed when, for example, it had been washed off by rain. Thus, $\mathrm{CaCO}_{3}$ was applied three times from 22 July to 28 Sept. 2008. The amount of $\mathrm{CaCO}_{3}$ particles
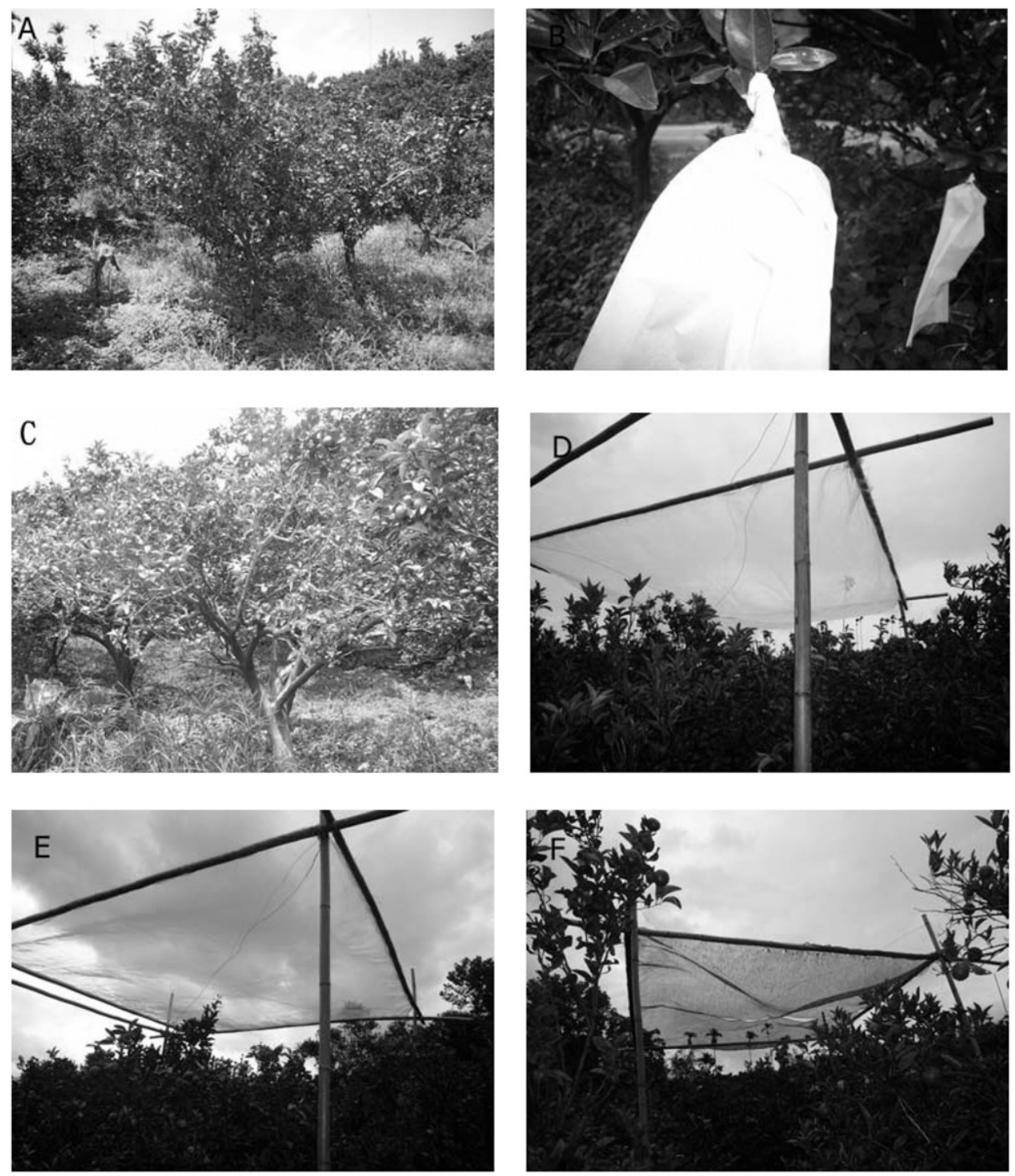

Fig. 1. Sunscald protection of 'Murcott' tangor fruit subjected to: (A) control, (B) white bagging, (C) calcium carbonate spraying, (D) white nylon net with a $20 \%$ shading rate, (E) green nylon net with a $30 \%$ shading rate, and (F) black nylon net with a $50 \%$ shading rate. 
deposited on leaf and fruit surface was estimated according to Jifon and Syvertsen (2003b). Foliar sprays using $3 \%$ of $\mathrm{CaCO}_{3}$ aqueous suspension had the average $( \pm \mathrm{SE}) 15 \pm 0.55 \mathrm{~g} \cdot \mathrm{m}^{-2}$ deposition on leaf and fruit surface. In Treatments 4, 5, and 6, effects of shade nets were examined, by using white nylon nets with a $20 \%$ shading rate, green nylon nets with a $30 \%$ shading rate, and black nylon nets with a $50 \%$ shading rate, all positioned roughly $50 \mathrm{~cm}$ above the citrus trees (Fig. 1D-F).

Data COLLECTION AND STATISTICAL ANALYSIS. The air temperature was collected under different shade nets (with $20 \%, 30 \%$, and $50 \%$ shading rates) using a sheltered probe (SK-L200TH; Sato Keiryoki, Tokyo, Japan) attached to a data logger (SK-L200TH $\alpha$; Sato Keiryoki) programmed to read the air temperature every $30 \mathrm{~min}$. The air temperature data were recorded at roughly $30 \mathrm{~cm}$ above the citrus trees within each shade net treatment from 26 Sept. to 31 Oct. 2008. Leaf temperatures were monitored using an infrared (IR) temperature sensor (MI 200; Apogee Instruments, Logan, UT). Leaf temperatures were recorded hourly (from 0800 to $1800 \mathrm{HR}$ ) on two mature leaves from different external shoots from each treatment (i.e., 8 to 10 leaves per tree per treatment). The IR digital thermometer was held at a distance $\approx 20 \mathrm{~cm}$ from the top of the leaf to prevent it from shading the target area. All leaf temperature data were averaged for a single measurement under different shade treatments from 26 Sept. to 31 Oct. 2008. The photosynthetic photon flux (PPF) was monitored during the experiment on selected clear days from 0800 to $1800 \mathrm{HR}$. PPF was recorded using an quantum sensors (LI-189; LI-COR, Lincoln, NE) attached to a portable photosynthesis system (LI-6200, LICOR) placed adjacent to two mature leaves from different external shoots under each treatment (i.e., 8 to 10 leaves per tree per treatment).

Sunscald was determined when yellow or brown blotches appeared on the citrus peel (Fig. 2). We investigated all fruit on every experimental tree every week for sunscald symptoms from 1 Aug. to 31 Oct. 2008, and expressed as a percentage of sunscald as follows: (number of fruit with sunscald) $/($ total fruit $) \times 100 \%$. Fifty
'Murcott' tangor fruit per tree per treatment were randomly harvested by hand and sent to the laboratory later the same day. The fresh weight and volume of the fruit were measured at the laboratory, in a room kept at $25^{\circ} \mathrm{C}$. Later, the 30 most uniformsized fruit (e.g., $\approx 21 \mathrm{~cm}$ circumference) picked from each treatment were divided into three groups for physiological analysis (i.e., 10 fruit per group). One group was used to measure juice percentage, TSS, TA, and TSS/TA ratio, a second group was used for peel color analysis, and a third group was used to determine the respiration rate.

Peel color analysis. Fruit samples were measured for $L, a$, and $b$ color values. Color was measured on both faces of all 10 fruit, which presented as fruit that appeared to have been sun exposed and shaded using a tristimulus colorimeter (CR 200; Minolta, Osaka, Japan), with a 5-mm aperture. In this system, $L$ represents color brightness, which is low for dark colors and high for bright ones; $a$ is negative for green and positive for red; and $b$ is negative for blue and positive for yellow. Hue angle expressed as a $\theta$ value, which is calculated as follows, $\theta$ value $=$ $1 /$ tangent $(\mathrm{b} / \mathrm{a})$. The readings were then averaged to represent peel color.

JUICE PERCENTAGE, TOTAL SOLUBLE SOLID, AND TITRATABLE ACID. Fruit pulps from the second group were recorded (grams/fruit) and then homogenized in a blender and filtrated to collect juice weight (grams/fruit). The juice percentage was calculated as follows: (juice weight)/ total weight (juice + pulp) $\times 100 \%$. A few drops of the fresh juice were placed on a refractometer (Mater-M, Tokyo, Japan) to measure TSS expressed as a percentage. Titratable acid was determined with $5 \mathrm{~mL}$ juice diluted 10 -fold, reacted with $0.1 \mathrm{~N}$ sodium hydroxide $(\mathrm{NaOH})$ to $\mathrm{pH} 8.2$, and the required milliliter of $\mathrm{NaOH}$ was recorded. Percent acid is calculated as follows: percent acid $=(N) \times(V 1) \times$ (Eq wt) $/ V 2$ where $N$ equals the normality of $\mathrm{NaOH}(0.1), V 1$ is the volume of $\mathrm{NaOH}$ used to reach the titration point, $\mathrm{Eq}$ wt is the equivalent weight of citric acid [the predominant acid (64 $\mathrm{mg}$ per milliequivalent)], and $V 2$ is the original volume of the sample $(5 \mathrm{~mL})$. The TSS/TA ratio is represented as percent sugar per percent acid.

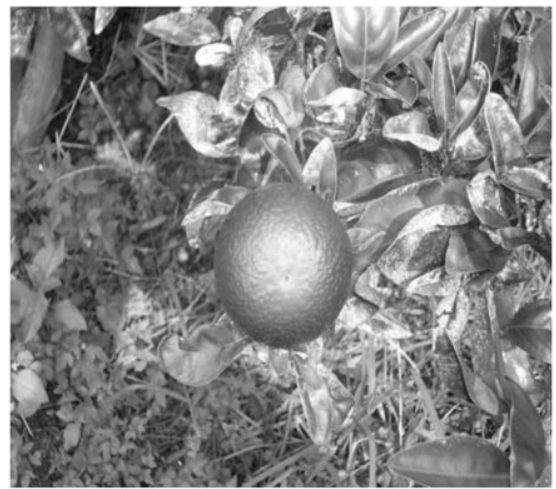

(A)

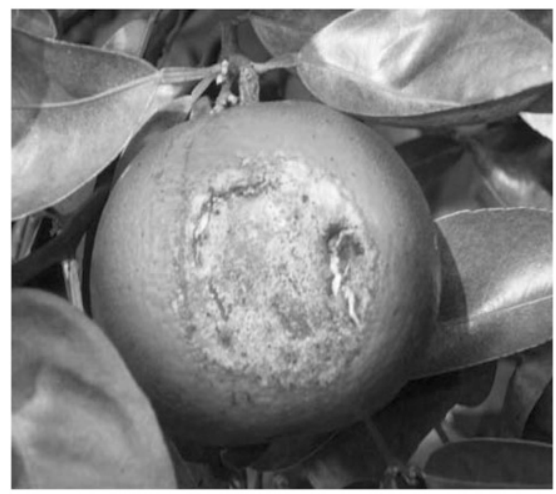

(B)

Fig. 2. Sunscald symptom of 'Murcott' tangor fruit: (A) slight sunscald in the initial stage. (B) serious sunscald in the later stage.

Postharvest Respiration RATE. The respiration rate is indicated as the $\mathrm{CO}_{2}$ production rate. Each fruit from the third group was weighed and then placed in a 2 - $\mathrm{L}$ sealed respiration jar at $25{ }^{\circ} \mathrm{C}$, and a $1-\mathrm{mL}$ gas sample was taken over a period of $2 \mathrm{~h}$ on each of the next $7 \mathrm{~d}$, and injected into a gas chromatograph (GC-8A; Shimadzu, Kyoto, Japan) to measure the $\mathrm{CO}_{2}$ concentration. Multiplying the change in concentration by the container volume and dividing this by weight of the fruit and duration of time gives the $\mathrm{CO}_{2}$ production rate. The readings were then averaged to represent the respiration rate.

LEAF NET PHOTOSYNTHESIS. Net photosynthesis by citrus foliage was determined with a portable photosynthesis system (LI-6200, LI-COR) equipped with a well-stirred $0.25-\mathrm{L}$ leaf chamber. Two fully expanded, similar leaves at the third positions of the external shoots per tree per treatment were sampled for photosynthesis 
determination every Saturday between 0800 and $1200 \mathrm{HR}$ in Oct. 2008.

Statistical analysis. Data were subjected to analysis of variance (ANOVA) using SAS (Version 9.2; SAS Institute, Cary, NC). Mean values among treatments were compared using a least significant difference (LSD) test at $5 \%(P \leq 0.05)$.

\section{Results}

Photosynthetic Photon Flux. An increase in $P P F$ was recorded over $1 \mathrm{~h}$ (i.e., 0800 to $0900 \mathrm{HR}$ ) in the morning, and the maximum PPF at midday was $\approx 1900 \mu \mathrm{mol} \cdot \mathrm{m}^{-2} \cdot \mathrm{s}^{-1}$ on a clear day of 10 Oct. 2008. Thereafter, $P P F$ declined during late afternoon, and fell below $500 \mu \mathrm{mol} \cdot \mathrm{m}^{-2} \cdot \mathrm{s}^{-1}$ at $1800 \mathrm{HR}$. The effects of the shading treatments on PPF are shown in Fig. 3. All treatments significantly reduced average PPF (white nylon net: $1090 \pm 32 \mu \mathrm{mol} \cdot \mathrm{m}^{-2} \cdot \mathrm{s}^{-1}$, green nylon net: $981 \pm 68 \mu \mathrm{mol} \cdot \mathrm{m}^{-2} \cdot \mathrm{s}^{-1}$, and black nylon net: $857 \pm 73 \mu \mathrm{mol} \cdot \mathrm{m}^{-2} \cdot \mathrm{s}^{-1}$, respectively) when compared with the control $\left(1304 \pm 67 \mu \mathrm{mol} \cdot \mathrm{m}^{-2} \cdot \mathrm{s}^{-1}\right)$.

Air AND LEAF TEMPERATURES. Each of the different shade nets decreased air temperatures $\left(3\right.$ to $4{ }^{\circ} \mathrm{C}$ lower than control). Shade nets with different shading rates $(20 \%, 30 \%$, and $50 \%$ ) resulted in lower average temperatures $\left(34.8,34.5\right.$, and $34.2^{\circ} \mathrm{C}$, respectively) in comparison with the control $\left(38.4{ }^{\circ} \mathrm{C}\right)$. The data showed that the highest temperature under the shading net treatments was over $38{ }^{\circ} \mathrm{C}$ during the observation period, but this was only for $1 \mathrm{~d}$. However, a temperature of over $40{ }^{\circ} \mathrm{C}$ for $10 \mathrm{~d}$ was recorded with the controls (Fig. 4).

In addition, leaf surface temperatures were also recorded, and the results showed that shading treatments reduced leaf surface temperatures compared with controls during the first 3 weeks (Table 1). In the final 3 weeks of the experiment, shading nets did not affect leaf temperature. Shading treatments significantly lowered leaf surface temperatures in comparison with the control, although there were no significant differences among the shading treatments. Even though leaf temperatures were slightly lower for the treatments than the control, no significant difference $(P>0.05)$ was observed after 15 Oct. during the experiment in 2008 .

SHADING EFFECTS ON SUNSCALD OCCURRENCE. All treatments were

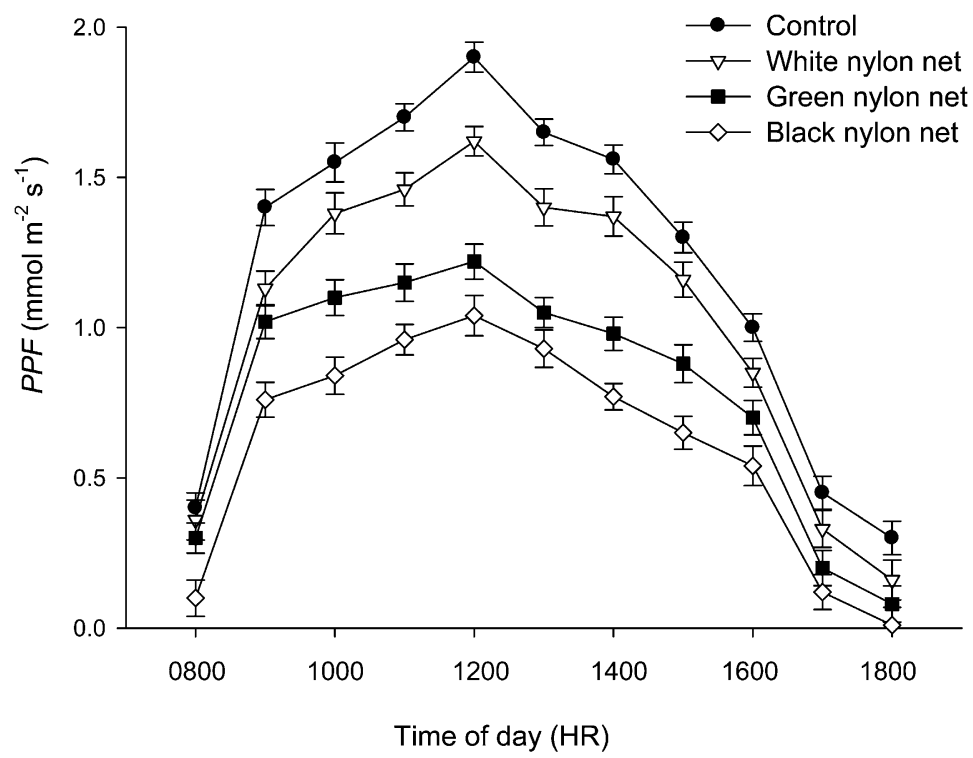

Fig. 3. Diurnal courses of incident photosynthetic photon flux (PPF) of 'Murcott' tangor leaves under various shading treatments on a clear day (10 Oct. 2008). Each value is the mean $\pm \operatorname{SE}(n=8-10)$ leaf measurement.

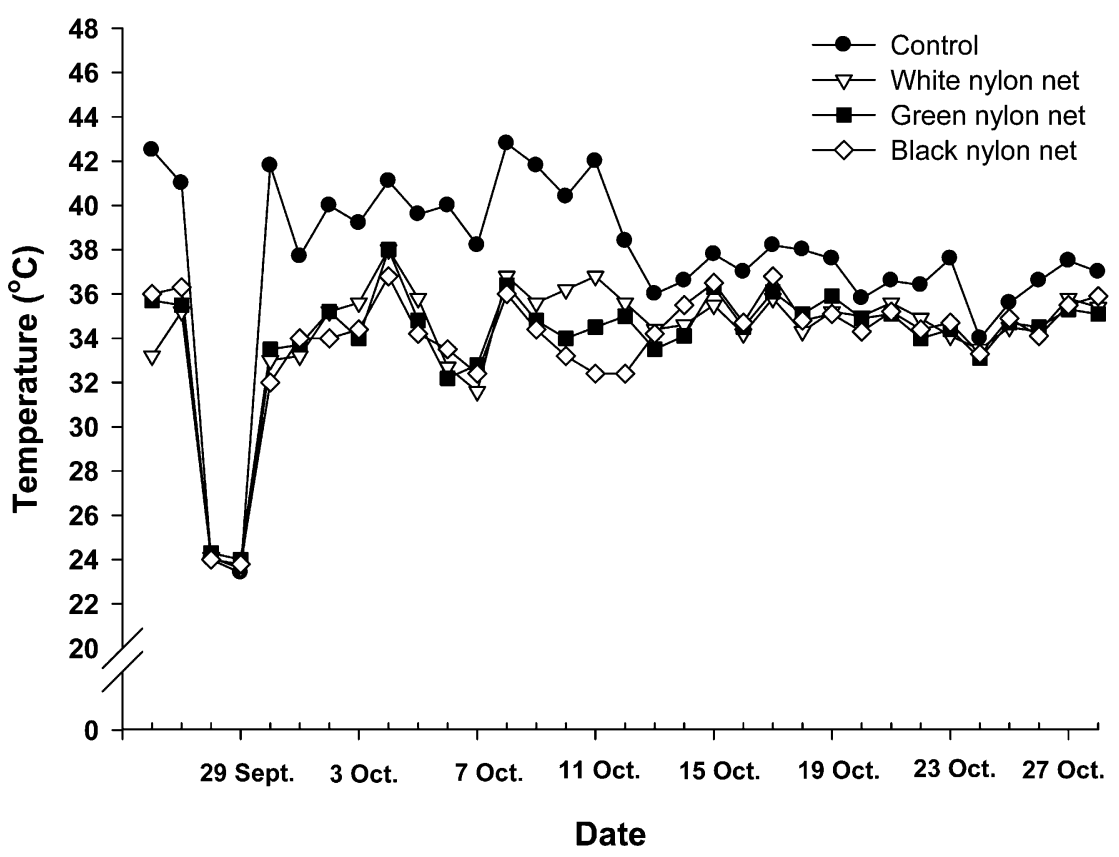

Fig. 4. Changes in air temperature of 'Murcott' tangor grown under various shading treatments (from 26 Sept. to 28 Oct. 2008).

successful in lowering the percentage of sunscald that occurred in 'Murcott' tangor fruit. When the fruit were covered with white paper bags then this reduced sunscald symptoms to $0 \%$, and the same results were found under nets with different shading rates. However, a low rate of sunscald, $4.4 \%$, was found for the fruit sprayed with $\mathrm{CaCO}_{3}$. In contrast, for the control fruit, grown without shading, there was a significant incidence of sunscald (13.6\%), as shown in Table 2 .

AnAlysis of FRUIT QUALITY. A significant difference in the fresh weight was found for the fruit samples grown under the black nylon net compared with the other treatments, among which there were no significant differences. Specifically, the highest fresh weight of 'Murcott' tangor fruit was measured (average $162.3 \mathrm{~g} /$ fruit) 
when shading with black nylon net, while the other conditions led to an average fresh weight ranged from 143.9 to $149.9 \mathrm{~g} /$ fruit (Table 3 ). In addition, similar results were seen in fruit volume. A significant difference in fruit volume was found (average $162.6 \mathrm{~cm}^{3} /$ fruit) when the 'Murcott' tangor tree were grown under the black nylon net, whereas those with the other treatments had average fruit volumes that ranged from 144.7 to $152.5 \mathrm{~cm}^{3} /$ fruit, without any significant differences (Table 3 ).

In addition, there were no significant differences among the treatments with regard to the four quality traits in 'Murcott' tangor fruit: peel color, TSS, TA, and TSS/TA. The average $L$ values ranged from 61 to 63 among all treatments. The 'Murcott' tangor fruit were harvested when ripe and when the peel was orange. Hue angle ranged from 65 to 69 , with no statistically significant differences among the treatments. The TSS ranged from $12.0 \%$ to $13.5 \%$ was not significantly different by shading applications. Similar results were seen in TA and TSS / TA. The average of TA and TSS/TA ranged from $0.81 \%$ to $0.93 \%$ and 14 to 16 , respectively, without any significant difference. This indicates that all the sunscald protection methods had similar averages for these four quality traits, with no effects on citrus quality and appearance in comparison with the control.

Postharvest respiration RATE. The postharvest respiration rate was measured after the fruit were placed in a $25{ }^{\circ} \mathrm{C}$ environment for $72 \mathrm{~h}$, and there was no significant difference in respiration rate among the treatments. All treatments resulted in a slight increase in respiration rate, from 11 to $16 \mathrm{~mL} \cdot \mathrm{kg}^{-1} \cdot \mathrm{h}^{-1} \mathrm{CO}_{2}$, but citrus fruit covered with white paper bags had a slight decrease from 13 to $11 \mathrm{~mL} \cdot \mathrm{kg}^{-1} \cdot \mathrm{h}^{-1} \mathrm{CO}_{2}$ from days 3 to 5 (data not shown). After that, the postharvest respiration rates changed little. Within treatment variability may have contributed to these changes, and there were no significant differences among the various antisunscald methods.

LEAF NET PHOTOSYNTHESIS. A significant difference in the net photosynthetic rate of leaf samples was found under different shading methods (Table 4). The $\mathrm{CaCO}_{3}$-sprayed treatment resulted in the lowest rates of

Table 1. Changes in leaf surface temperature of 'Murcott' tangor grown under various shading treatments.

\begin{tabular}{lllllll}
\hline & \multicolumn{7}{c}{ Leaf temperature $\left({ }^{\circ} \mathbf{C}\right)^{\mathrm{y}}$} \\
\cline { 2 - 7 } Treatment $^{\mathrm{z}}$ & Week 1 & Week 2 & Week 3 & Week 4 & Week 5 & Week 6 \\
\hline Control $^{38.2 \mathrm{a}^{\mathrm{x}}}$ & $43.3 \mathrm{a}$ & $44.0 \mathrm{a}$ & $39.6 \mathrm{a}$ & $38.4 \mathrm{a}$ & $38.0 \mathrm{a}$ \\
${\text { Spray } \mathrm{CaCO}_{3}{ }^{\mathrm{w}}}^{34.7 \mathrm{~b}}$ & $36.2 \mathrm{~b}$ & $37.3 \mathrm{~b}$ & $36.6 \mathrm{a}$ & $36.3 \mathrm{a}$ & $36.5 \mathrm{a}$ \\
White nylon net & $29.8 \mathrm{c}$ & $35.0 \mathrm{~b}$ & $35.4 \mathrm{~b}$ & $34.8 \mathrm{a}$ & $34.9 \mathrm{a}$ & $34.7 \mathrm{a}$ \\
Green nylon net & $30.6 \mathrm{c}$ & $33.6 \mathrm{~b}$ & $34.5 \mathrm{~b}$ & $33.9 \mathrm{a}$ & $34.8 \mathrm{a}$ & $34.5 \mathrm{a}$ \\
Black nylon net & $30.4 \mathrm{c}$ & $33.4 \mathrm{~b}$ & $33.7 \mathrm{~b}$ & $33.1 \mathrm{a}$ & $33.7 \mathrm{a}$ & $33.7 \mathrm{a}$ \\
\hline
\end{tabular}

${ }^{\mathrm{z}}$ Shading treatments were applied on 22 July 2008.

y Data were recorded hourly (from 0800 to $1800 \mathrm{HR}$ ) from 26 Sept. to 31 Oct. 2008. Data are the means of two mature leaves from different external shoots from each treatment; $\left(1.8 \times{ }^{\circ} \mathrm{C}\right)+32={ }^{\circ} \mathrm{F}$.

${ }^{x}$ Values for each column with different letters are statistically different by least significant difference (LSD) test at $P \leq 0.05$.

${ }^{\mathrm{w}}$ Calcium carbonate.

Table 2. Effect of shading treatments on canopy temperature and occurrence of sunscald in 'Murcott' tangor fruit.

\begin{tabular}{lcc}
\hline Treatment $^{\mathrm{z}}$ & Canopy temp $\left({ }^{\circ} \mathbf{C}\right)^{\mathrm{y}}$ & ${\text { Sunscald }(\%)^{\mathrm{x}}}^{\mathrm{x}}$ \\
\hline Control & $38.4 \mathrm{a}^{\mathrm{w}}$ & $13.6 \mathrm{a}$ \\
White paper bag & $38.1 \mathrm{a}$ & $0.0 \mathrm{c}$ \\
Spray CaCO $_{3}^{\mathrm{v}}$ & $36.7 \mathrm{ab}$ & $4.4 \mathrm{~b}$ \\
White nylon net & $34.2 \mathrm{~b}$ & $0.0 \mathrm{c}$ \\
Green nylon net & $33.7 \mathrm{~b}$ & $0.0 \mathrm{c}$ \\
Black nylon net & $33.1 \mathrm{~b}$ & $0.0 \mathrm{c}$ \\
\hline
\end{tabular}

${ }^{2}$ Shading treatments were applied on 22 July 2008.

${ }^{\mathrm{y}}$ Data are the means of three replications; $\left(1.8 \times{ }^{\circ} \mathrm{C}\right)+32={ }^{\circ} \mathrm{F}$.

${ }^{\mathrm{x}}$ Sunscald was investigated every week from 1 Aug. to 31 Oct. 2008, and expressed as a percentage of sunscald as follows: (number of fruit with sunscald) $/$ (total fruit) $\times 100 \%$.

"Values in a column with different letters are statistically different by least significant difference (LSD) test at $P \leq 0.05$.

"Calcium carbonate.

Table 3. Effect of shading treatments on fresh weight, fruit volume, and juice percentage on 'Murcott' tangor fruit.

\begin{tabular}{|c|c|c|c|}
\hline Treatment $^{z}$ & $\begin{array}{l}\text { Fresh wt } \\
(\mathrm{g} / \text { fruit })^{\mathrm{y}}\end{array}$ & $\begin{array}{c}\text { Fruit vol } \\
\left(\mathrm{cm}^{3} / \text { fruit }\right)^{\mathrm{y}}\end{array}$ & $\begin{array}{c}\text { Juice } \\
\text { percentage }(\%)^{x}\end{array}$ \\
\hline Control & $147.4 \mathrm{~b}^{\mathrm{w}}$ & $149.0 \mathrm{~b}$ & $54.9 \mathrm{a}$ \\
\hline White paper bag & $148.0 \mathrm{~b}$ & $148.3 \mathrm{~b}$ & $56.2 \mathrm{a}$ \\
\hline Spray $\mathrm{CaCO}_{3}^{\mathrm{v}}$ & $149.9 \mathrm{~b}$ & $152.5 \mathrm{~b}$ & $48.6 \mathrm{a}$ \\
\hline White nylon net & $143.9 \mathrm{~b}$ & $144.7 \mathrm{~b}$ & $49.8 \mathrm{a}$ \\
\hline Green nylon net & $144.5 \mathrm{~b}$ & $144.8 \mathrm{~b}$ & $51.2 \mathrm{a}$ \\
\hline Black nylon net & $162.3 \mathrm{a}$ & $162.7 \mathrm{a}$ & $51.2 \mathrm{a}$ \\
\hline
\end{tabular}

${ }^{\mathrm{z}}$ Shading treatments were applied on 22 July 2008.

y Data are the means of 50 fruit; $1 \mathrm{~g}=0.0353 \mathrm{oz}, 1 \mathrm{~cm}^{3}=0.0610 \mathrm{inch}^{3}$.

${ }^{x}$ Data are the means of 10 fruit; juice percentage is expressed as follows: (juice weight)/total weight (juice + pulp) $\times$ $100 \%$.

"Values in a column with different letters are statistically different by least significant difference (LSD) test at $P \leq 0.05$.

${ }^{\mathrm{V}}$ Calcium carbonate.

net photosynthesis $\left(8.8 \mu \mathrm{mol} \cdot \mathrm{m}^{-2} \cdot \mathrm{s}^{-1}\right)$ among shading practice while the other ones showed no significant differences. When in comparison of colored shade nettings, the lower net photosynthetic rate was measured under black shade net (Table 4).

\section{Discussion}

This study found that sunscald occurred on 'Murcott' tangor fruit due to high temperature. The direct sunlight exposure with high solar radiation may possibly cause sunscald occurrence although we lack fruit surface temperature. There was $0 \%$ of sunburn when 'Murcott' tangor fruit were covered with shade nets with the average leaf temperature of $\approx 33.7^{\circ} \mathrm{C}$ accompanied by lower $P P F$ [white nylon net: $($ mean \pm SE) $1090 \pm$ $32 \mu \mathrm{mol} \cdot \mathrm{m}^{-2} \cdot \mathrm{s}^{-1}$, green nylon net: 
Table 4. Comparison with net photosynthetic rate of 'Murcott' tangor leaves in the field.

\begin{tabular}{|c|c|}
\hline Treatment $^{\mathrm{z}}$ & $\begin{array}{c}\text { Net photosynthetic } \\
\text { rate } \\
{\left[\mathrm{CO}_{2}\left(\mu \mathrm{mol} \cdot \mathrm{m}^{-2} \cdot \mathrm{s}^{-1}\right)\right]^{\mathrm{y}}}\end{array}$ \\
\hline Control & $11.5 a^{x}$ \\
\hline $\begin{array}{l}\text { White paper } \\
\text { bag }\end{array}$ & $11.5 \mathrm{ab}$ \\
\hline Spray $\mathrm{CaCO}_{3}{ }^{\mathrm{w}}$ & $8.8 \mathrm{c}$ \\
\hline $\begin{array}{l}\text { White nylon } \\
\text { net }\end{array}$ & $12.6 \mathrm{a}$ \\
\hline $\begin{array}{l}\text { Green nylon } \\
\text { net }\end{array}$ & $12.1 \mathrm{a}$ \\
\hline $\begin{array}{l}\text { Black nylon } \\
\text { net }\end{array}$ & $10.3 \mathrm{~b}$ \\
\hline \multicolumn{2}{|c|}{$\begin{array}{l}{ }^{2} \text { Shading treatments were applied on } 22 \text { July } 2008 \text {. } \\
\text { 'Net photosynthesis measurement conducted during } \\
0800 \text { to } 1100 \mathrm{HR} \text { on } 3,10 \text {, and } 17 \text { Oct. } 2008 \text {. } \\
\text { "Values in a column with different letters are statisti- } \\
\text { cally different by least significant difference (LSD) test } \\
\text { at } P \leq 0.05 \text {. } \\
\text { "Calcium carbonate. }\end{array}$} \\
\hline
\end{tabular}

$981 \pm 68 \mu \mathrm{mol} \cdot \mathrm{m}^{-2} \cdot \mathrm{s}^{-1}$, and black nylon net: $857 \pm 73 \mu \mathrm{mol} \cdot \mathrm{m}^{-2} \cdot \mathrm{s}^{-1}$ ]. The same result with regard to the occurrence of sunscald on 'Murcott' tangor fruit was seen when white paper bags covered on each fruit, even when the leaf temperature and $P P F$ were the same as with the control fruit. It is thus possible that white color paper bags are less endothermic, which lowered the temperature inside the bag to create a microclimate for bagging (Hofman et al., 1997), and white paper bags may have a similar effect in reducing $P P F$ and blocking direct sunlight to that seen with white shade nets. Schrader et al. (2001) reported that the most serious sunscald happens to apples when the fruit skin temperature reaches $52{ }^{\circ} \mathrm{C}$. In addition, Schrader et al. (2003) found a correlation $(r=0.90)$ between the temperature of the orchard and apple fruit surface, and that when the ambient temperature of the former was over $30^{\circ} \mathrm{C}$, the latter reached $46^{\circ} \mathrm{C}$, at which point sunscald occurred in apple. Chikaizumi (2007) reported similar findings in a study of "Wase Satsuma' mandarin orange (C. reticulata), and showed that when the average temperature of the orchard was at least $30{ }^{\circ} \mathrm{C}$, the peel temperature reached $46.8^{\circ} \mathrm{C}$, resulting in sunscald symptoms. Sun-exposed fruit suffered radiation heat, which resulted in peel temperature reached to $40{ }^{\circ} \mathrm{C}$ (Chikaizumi, 2007). In this study, the average temperatures under different shading treatments were $\approx 34.5{ }^{\circ} \mathrm{C}$, and thus these effectively decreased air temperatures in comparison with the control $\left(38.4^{\circ} \mathrm{C}\right)$. Although $\mathrm{CaCO}_{3}$ spray led to a lower leaf temperature, $4.4 \%$ of sunscald still occurred with 'Murcott' tangor fruit treated in this way. This may be because the fruit suffered high temperature and/or radiation damage during the intervals between respraying with $\mathrm{CaCO}_{3}$, since the fruit-bearing branches of 'Murcott' tangor trees protrude from the canopy, and thus are exposed to direct sunlight. Second, even though the whole 'Murcott' tangor canopy was sprayed with $\mathrm{CaCO}_{3}$, some spots on the surface of the fruit may have remained uncovered by $\mathrm{CaCO}_{3}$, resulting in sunscald.

A previous study showed that changes in pigments concentration are associated with the degree of sunburn in apples (Felicetti and Schrader, 2008). Furthermore, Chikaizumi (2007) pointed out that when sunburn symptoms appear on sun-facing mandarin the fruit surface temperature of brown blotches is $\approx 46.8^{\circ} \mathrm{C}$, that of yellow blotches is $44.2^{\circ} \mathrm{C}$, and the rest of the green peel is $42^{\circ} \mathrm{C}$. Although we did not measure fruit surface temperature, or the chlorophyll and carotenoid content of the fruit, the peel of 'Murcott' tangor fruit does not become yellow-orange until late November. Before this, the fruit skin color is still green, and is thus able to absorb PPF used in photosynthesis, even if it has less photosynthetic capacity than the leaves (Cheng and Ma, 2004). The excess PPF that exists in fruit peel with a lower stomatal density results in a high surface temperature of the peel than that seen with the leaves under sunlight (Glenn et al., 2002). Cheng and Ma (2004) indicated that the xanthophyll cycle functions as a form of heat dissipation in apple fruit peel when absorbing excessive PPF. However, when high temperatures are coupled with high light intensity, this can result in the photoinhibition of the photosystem II (PSII) due to a decrease in the heat dissipation capacity via the xanthophyll cycle (Cheng and $\mathrm{Ma}, 2004$; Cheng et al., 2008; Ort, 2001). In addition, high fruit peel temperature results in disruption of the electrons transportation from the oxygen-evolving complex to the PSII reaction centers, which make the PSII more sensitive to high light damage in apples (Cheng et al., 2008). However, in our study, the shade net treatments not only lowered the temperature and reduced the PPF but blocked direct sunlight exposure, which resulted in $0 \%$ sunscald on 'Murcott' tangor fruit. Even though the peel color is still green, further studies are needed to clarify whether changes in carotenoids, particularly xanthophylls, and chlorophylls are related to sunburn in 'Murcott' tangor fruit.

Pe'rez et al. (2006) mentioned that colored shade nets can affect environmental elements (e.g., humidity, shade, or temperature), thus affecting light quality and quantity. Different colored shade nets can increase light scattering, thereby influencing plant development and growth (Stamps, 2009). In our study, shade nets were used for radiation reduction, which is in agreement with Stamps (2009), who pointed out that shade nets can reduce radiation regardless of colors.

Glenn et al. (2002) and Gindaba and Wand (2005) reported that kaolin particle film was effective to decrease apple surface temperature and reflect ultraviolet. $\mathrm{CaCO}_{3}$ spray is an alternative method, which is similar to kaolin particle film technology used in citrus orchard in Taiwan. Kaolin particle film and $\mathrm{CaCO}_{3}$ spray are both effective methods to decrease fruit surface temperatures; however, the $\mathrm{CaCO}_{3}$ solution was resprayed if needed when washed off by rain. When comparing paper bags, $\mathrm{CaCO}_{3}$, and shade nets with regard to sunscald protection of 'Murcott' tangor, sunscald was eliminated with the use of white paper bagging and shade nets, and significantly reduced with $\mathrm{CaCO}_{3}$ spraying (Table 2).

Jifon and Syvertsen (2001) reported that 'Hamlin' sweet orange (C. sinensis) had greener fruit (a smaller hue angle) than control fruit when grown under a shade net with a $50 \%$ shading rate. In this study, the 'Murcott' fruit examined were all mature before being measured, as the pericarp was gradually turning yelloworange. Although shade nets were the most effective technique in reducing ambient temperatures and the occurrence of sunscald, the 'Murcott' tangor fruit grown under the shade nets had very similar color to those grown using other shading methods, as well as the control fruit. 
The high temperatures of leaves and fruit usually cause water shortages and reduce growth, net photosynthesis, fruit yield and quality (Goldschmidt, 1999). This study found that fruit weight and volume significantly increased under black shade net treatment, which reduced temperature and PPF. Shading effectively lowered leaf temperatures and $P P F$ but had no significant effect on the quality of the 'Murcott' tangor fruit, as indicated by the TSS, TA, and TSS/TA in comparison with the control. Our findings also showed that the fruit sprayed with $\mathrm{CaCO}_{3}$ resulted in low net photosynthetic rate of $8.8 \mu \mathrm{mol} \cdot \mathrm{m}^{-2} \cdot \mathrm{s}^{-1}$ and low TSS of $12.0 \%$, and this is in agreement with Frommer and Sonnewald (1995), who observed that $\mathrm{CaCO}_{3}$ spraying affected leaf photosynthesis, leading to less accumulation of TSS.

Shading affected $P P F$ and consequently leaf temperatures when compared with the control (Fig. 3). Both high $P P F$ and high temperature can damage PSII, affecting the electron transportation (Cheng et al., 2008). The average air temperature in this study was over $38^{\circ} \mathrm{C}$, and sun-exposed (control) leaf temperatures were 2 to $6{ }^{\circ} \mathrm{C}$ higher than air temperatures and easily exceeded $40{ }^{\circ} \mathrm{C}$ (Fig. 4). Therefore, accumulated heat stress could have limited photosynthesis (Law and Crafts-Brandner, 1999), in agreement with Koch (1984), who reported a reduced leaf photosynthetic rate in citrus. Furthermore, Torres et al. (2006) reported that high temperatures alone can reduce photosynthetic efficiency by $53 \%$ which may possibly result from photooxidative stress.

Citrus are classified as nonclimacteric fruit with little ethylene production, no significant respiratory peak, and no ripening after harvest (Soule and Grierson, 1986). In this study, we did not observe any significant differences in the respiration rates among treatments, and a steady state was reached with an average respiration rate from 11 to $16 \mathrm{~mL} \cdot \mathrm{kg}^{-1} \cdot \mathrm{h}^{-1}$ $\mathrm{CO}_{2}$ in agreement with a former study (Eaks, 1970).

A previous study showed that whitewashes are effective antitranspirants to lower leaf temperature (Gale and Hagan, 1966), while Abou-Khaled et al. (1970) reported that kaolin is able to reflect ultraviolet light, decrease transpiration, and lower leaf temperature, and Wand et al. (2002) suggested that at lower ambient temperatures trees had more stomatal conductance, leading to a greater leaf photosynthetic rate. Furthermore, Jifon and Syvertsen $(2001,2003 a)$ and Medina et al. (2002) reported that moderate shading enhanced net photosynthesis in citrus leaves by reducing the light inhibition and lowering excessively high temperatures. Although shading nets had comparable effects to those of $\mathrm{CaCO}_{3}$ spraying with regard to the reducing temperature, Lambers et al. (1998) found that shading reduced the photosynthetic rate of leaves. However, our study had the opposite results, with white and green nylon nets $(20 \%$ and $30 \%$ shading rates, respectively) leading to a significantly higher photosynthetic rate, and $\mathrm{CaCO}_{3}$ spraying resulting in the lowest photosynthetic rate (Table 4 ) probably because excessive $\mathrm{CaCO}_{3}$ particles inhibit gas exchange.

\section{Conclusions}

Although it was not the intent of this study to determine the temperature at which the varying degrees of sunscald occur, the results support the notion that increased sunburn severity is the result of increased exposure to light or heat stress. Growers can thus decrease the incidence of sunscald browning by using management practices that keep fruit from attaining a high peel temperature, or that block or reflect harmful ultraviolet radiation. We used different shading techniques and evaluated their effectiveness with regard to sunscald and fruit quality. $\mathrm{CaCO}_{3}$ spraying, shade nets, and white paper bagging all significantly reduced the occurrence of sunscald, and had no significant differences with regard to fruit appearance, TSS/TA, and juice percentage. Although $\mathrm{CaCO}_{3}$ spraying is easier and faster than the other methods (spraying as needed) the need to remove the $\mathrm{CaCO}_{3}$ deposits at harvest may require another system to wash off the residue (Le Grange et al., 2004; Schupp et al., 2002).

Although white paper bagging was able to reduce the occurrence of sunscald, it is a labor-intensive process, which thus may limit its practical use. Shade nets were effective in reducing both temperature and sunscald in 'Murcott' tangor fruit, in addition, leading to higher photosynthetic rates, as well as being relatively cheap and fast to apply. Shade nets could thus be a very useful technique to protect citrus fruit against sunscald without influencing fruit quality in commercial citrus farms.

\section{Literature cited}

Abou-Khaled, A., R.M. Hagan, and D.C. Davenport. 1970. Effects of kaolinite as a reflective antitranspirant on leaf temperature, transpiration, photosynthesis, and water use efficiency. Water Resources Res. 6:280-289.

Andrews, P.K., J.R. Johnson, and D. Fahy. 1999. Protection of apple against sunscald using treatments with ascorbic acid. Fruit-Belge 67:157-161.

Bergh, O., J. Franken, E.J. Van Xyl, F. Kloppers, and A. Dempers. 1980. Sunburn on apple-preliminary results of an investigation conducted during the 1978/79 season. Deciduous Fruit Grower 30:8-22.

Cheng, L., L.S. Chen, and P. Li. 2008. Effects of high temperature coupled with high light on the balance between photooxidation and photoprotection in the sun-exposed peel of apple. Planta 228: 745-756.

Cheng, L. and F.W. Ma. 2004. Diurnal operation of the xanthophyll cycle and the antioxidant system in apple peel. J. Amer. Soc. Hort. Sci. 129:313-320.

Chikaizumi, S. 2000. Mechanisms of rindoil spot development in 'Encore'(Citrus nobilis Lour. $\times C$. deliciosa Ten.) fruit. J. Jpn. Soc. Hort. Sci. 69:149-155.

Chikaizumi, S. 2007. Studies on causal factors and preventive measures of rind disorders in citrus fruit. Memoirs Faculty Agr. Ehime Univ. 52:13-28.

Dussi, M.C., G. Giardina, D. Sosa, R. González Junyent, A. Zecca, and P. Reeb. 2005. Shade nets effect on canopy light distribution and quality of fruit and spur leaf on apple cv. Fuji. Spanish J. Agr. Res. 3:253-260.

Eaks, I.L. 1970. Respiratory response, ethylene production, and response to ethylene of citrus fruit during ontogeny. Plant Physiol. 45:334-338.

Felicetti, D.A. 2003. Characterization of a third type of apple sunburn caused by sudden exposure of shaded apples to sunlight. MS Thesis, Washington State Univ., Pullman, WA.

Felicetti, D.A. and L.E. Schrader. 2008. Changes in pigment concentrations associated with the degree of sunburn 
browning of 'Fuji' apple. J. Amer. Soc. Hort. Sci. 133:27-34.

Frommer, W.B. and U. Sonnewald. 1995. Molecular analysis of carbon portioning in solanaceous species. J. Expt. Bot. 46:587607.

Futch, S.H. and L.K. Jackson. 1993. Murcott (Honey Tangerine). Fact Sheet HS-174, Univ. Florida, Inst. Food Agr. Sci., Coop. Ext Serv.

Goldschmidt, E.E. 1999. Carbohydrate supply as a critical factor for citrus fruit development and productivity. HortScience 34:1020-1024.

Gale, J. and R.M. Hagan. 1966. Plant antitranspirants. Annu. Rev. Plant Physiol. 17:269-282.

Gindaba, J. and S.J.E. Wand. 2005. Comparative effects of evaporative cooling, kaolin particle film, and shade net on sunburn and fruit quality in apples. HortScience 40:592-596.

Glenn, D.M., E. Prado, A. Erez, J. McFerson, and G.J. Puterka. 2002. A reflective processed-kaolin particle film affects fruit temperature, radiation reflection and sunburn in apples. J. Amer. Soc. Hort. Sci. 127:188-193.

Greer, D.H. and D.L. Borde. 2006. Sunburn of grapes affects wine quality. Austral. N. Z. Grapegrower Winemaker 506:21-23.

Hofman, P.J., L.G. Smith, D.C. Joyce, G.I. Johnson, and G.F. Meiburg. 1997. Bagging of mango (Mangifera indica $c v$. Keitt) fruit influences fruit quality and mineral composition. Postharvest Biol. Technol. 12:83-91.

Jifon, J.L. and J.P. Syvertsen. 2001. Effects of moderate shade on citrus leaf gas exchange, fruit yield, and quality. Proc. Florida Hort. Soc. 114:177-181.

Jifon, J.L. and J.P. Syvertsen. 2003a. Kaolin particle film applications can increase photosynthesis and water use efficiency of 'Ruby Red' grapefruit leaves. J. Amer. Soc. Hort. Sci. 128: 107-112.

Jifon, J.L. and J.P. Syvertsen. 2003b. Moderate shade can increase net gas exchange and reduce photoinhibition in citrus leaves. Tree Physiol. 23:119-127.

Johnson, J.R., D. Fahy, and N. Gish. 1999. Influence of ascorbic acid sprays on apple sunburn. Good Fruit Grower 50:8183.

Kliewer, M.W. and L.A. Lider. 1968. Influence of cluster exposure to the sun on the composition of Thompson seedless fruit. Amer. J. Enol. Viticult. 19:175184.
Koch, K.E. 1984. The path of photosynthate translocation into citrus fruit. Plant Cell Environ. 7:647-653.

Law, R.D. and S.J. Crafts-Brandner. 1999. Inhibition and acclimation of photosynthesis to heat stress is closely correlated with activation of ribulose1,5-bisphosphate carboxylase/oxygenase. Plant Physiol. 120:173-181.

Lambers, H., F.S. Chapin, and T.L. Pons. 1998. Plant physiological ecology. Springer-Verlag, NY.

Le Grange, M., S.J.E. Wand, and K.I. Theron. 2004. Effect of kaolin applications on apple fruit quality and gas exchange of apple leaves. Acta Hort. 636:545-550.

Medina, C.L., R.P. Souza, E.C. Machado, R.V. Ribeiro, and J.A.B. Silva. 2002. Photosynthetic response of citrus grown under reflective aluminized polypropylene shading nets. Sci. Hort. 96:115-125.

Melgarejo, P., J.J. Martinez, F. Hemandez, R. Martinez-Font, P. Barrows, and A. Erez. 2004. Kaolin treatment to reduce pomegranate sunburn. HortScience 100:349353.

Morse, J.G. and C.A. Robertson. 1987. Calculating canopy area of citrus trees and surface area of fruits. Fla. Entomol. 70:168-171.

Myhob, M.A., L.F. Guindy, and S.E. Salem. 1996. Influence of sunburn on balady mandarin fruit and its control. Bul. Cairo Univ. Fac. Agr. 47:457-469.

Ort, D.R. 2001. When there is too much light. Plant Physiol. 125:29-32.

Parchomchuk, P. and M. Meheriuk. 1996. Orchard cooling with pulsed overtree irrigation to prevent solar injury and improve fruit quality of 'Jonagold' apples. HortScience 31:802-804.

Pe'rez, M., B.M. Plaza, S. Jime'nez, M.T. Lao, J. Barbero, and J.L. Bosch. 2006. The radiation spectrum through ornamental net houses and its impact on the climate generated. Acta Hort. 719:631-636.

Piskolczi, M., C. Varga, and J. Racskó. 2004. A review of the meteorological causes of sunburn injury on the surface of apple fruit (Malus domestica Borkh). J. Fruit Ornamental Plant Res. 12:245252.

Rabinowitch, H.D., N. Kedar, and P. Budowski. 1974. Induction of sunscald damage in tomatoes under natural and controlled conditions. Sci. Hort. 2:265272.

Raveh, E., S. Cohen, T. Raz, D. Yakir, A. Grava, and E.E. Goldschmidt. 2003. Increased growth of young citrus trees under reduced radiation load in a semiarid climate. J. Expt. Bot. 54:365-373.

Ritenour, M.A., S. Kochhar, and L.E. Schrader. 2001. Characterization of heat shock protein expression in apple peel under field and laboratory conditions. J. Amer. Soc. Hort. Sci. 126:564570.

Stamps, R.H. 2009. Use of colored shade netting in horticulture. HortScience 44: 239-241.

Schrader, L.E., J. Zhang, and W.K. Duplaga. 2001. Two types of sunburn in apple caused by high fruit surface (peel) temperature. Plant Health Prog. doi: 10.1094/PHP-2001-1004-01-RS.

Schrader, L.E., J. Zhang, and J. Sunday. 2003. Environmental stresses that cause sunburn of apple. Acta Hort. 618:397403.

Schroeder, C.A. 1965. Temperature relationships in fruit tissues under extreme conditions. Proc. Amer. Soc. Hort. Sci. 87:199-203.

Schroeder, C.A. and E. Kay. 1961. Temperature conditions and tolerance of avocado fruit tissue. California Avocado Soc. $45: 87-92$.

Schupp, J.R., E. Fallahi, and I. Chun. 2002. Effect of particle film on fruit sunburn, maturity and quality of 'Fuji' and 'Honeycrisp' apple. HortTechnology 12:87-90.

Sibbett, C.S., W.C. Micke, F.G. Mitchell, G. Mayer, and J.T. Yeager. 1991. Effect of topically applied whitener on sun damage to Granny Smith apples. Calif. Agr. 45:910.

Simpson, J., C.R. Rom, and M. Patterson. 1988. Causes and possible controls of sunburn on apples. Good Fruit Grower 39:16-17.

Smart, R.E. and T.R. Sinclair. 1976. Solar heating of grape berries and other spherical fruit. Agr. Meteorol. 17:241-256.

Spiegel-Roy, P. and E.E. Goldschmidt. 1996. Biology of citrus. Cambridge Univ. Press, Cambridge, UK.

Soule, J. and W. Grierson. 1986. Anatomy and physiology, p. 23-48. In: W.F. Wardowski, S. Nagy, and W. Grierson (eds.). Fresh citrus fruit. AVI Nostrand Reinhold, NY.

Syvertsen, J.P. and L.G. Albrigo. 1980. Some effects of grapefruit tree canopy position on microclimate, water relations, fruit yield, and juice quality. J. Amer. Soc. Hort. Sci. 105:454-459.

Syvertsen, J.P. and J. Lloyd. 1994. Citrus, p. 65-99. In: B. Schaffer and P.C. Andersen 
(eds.). Handbook of environmental physiology of fruit crops. Vol. II. Subtropical and tropical crops. CRC Press, Boca Raton, FL.

Tarara, J.M. and S.D. Spayd. 2005. Tackling 'sunburn' in red wine grapes through temperature and sunlight exposure. Good Fruit Grower 56:40-41.

Torres, C.A., P.K. Andrews, and N.M. Davies. 2006. Physiological and biochemical responses of fruit exocarp of tomato
(Lycopersicon esculentum Mill.) mutants to natural photo-oxidative conditions. J. Expt. Bot. 57:1933-1947.

Wand, S.J.E., W.J. Steyn, M.J. Mdluli, S.J.S. Marais, and G. Jacobs. 2002. Overtree evaporative cooling for fruit quality enhancement. SA Fruit J. (Aug.-Sept.):18-21.

Wand, S.J.E., K.I. Theron, J. Ackerman, and S.J.S. Marais. 2006. Harvest and post-harvest apple fruit quality following application of kaolin particle film in
South African orchards. Sci. Hort. 107:271-276.

Warner, G. 1997. Sunburn is a hot topic in orchards of Washington. Good Fruit Grower 48:22-23.

Woolf, A.B. and I.B. Ferguson. 2000. Postharvest responses to high fruit temperatures in the field. Postharvest Biol. Technol. 21:7-20. 